\title{
Correction to: Multivariate linear regression models for predicting metal content and sources in leafy vegetables and human health risk assessment in metal mining areas of Southern Jharkhand, India
}

\author{
Soma Giri ${ }^{1}\left[\right.$ ] Mukesh Kumar Mahato ${ }^{1} \cdot$ Abhay Kumar Singh ${ }^{1}$ \\ Published online: 17 February 2021 \\ (C) Springer-Verlag GmbH Germany, part of Springer Nature 2021
}

Correction to: Environmental Science and Pollution Research https://doi.org/10.1007/s11356-021-12494-9

The entries in the $3^{\text {rd }}$ column of Table are overlapping. The original article has been corrected.

Publisher's note Springer Nature remains neutral with regard to jurisdictional claims in published maps and institutional affiliations.

The online version of the original article can be found at https://doi.org/ 10.1007/s11356-021-12494-9

\footnotetext{
Soma Giri

soma0307@gmail.com

1 Natural Resources and Environmental Management Group,

CSIR-Central Institute of Mining and Fuel Research, Barwa Road,

Dhanbad 826015, India
} 